\title{
Short communication: Characteristics of student success in an undergraduate physiology and anatomy course
}

\author{
F. C. Gwazdauskas, ${ }^{1}$ M. L. McGilliard, and B. A. Corl \\ Department of Dairy Science, Virginia Polytechnic Institute and State University, Blacksburg 24061-0315
}

\begin{abstract}
Several factors affect the success of students in college classes. The objective of this research was to determine what factors affect success of undergraduate students in an anatomy and physiology class. Data were collected from 602 students enrolled in the Agriculture and Life Sciences (ALS) 2304 Animal Physiology and Anatomy course from 2005 through 2012. The data set included 476 females (79.1\%) and 126 males (20.9\%). Time to complete exams was recorded for each student. For statistical analyses, students' majors were animal and poultry sciences (APSC), agricultural sciences, biochemistry, biological sciences, dairy science, and "other," which combined all other majors. All analyses were completed using the GLIMMIX procedure of SAS (SAS Institute Inc., Cary, NC). Gender, major, matriculation year, major by year interaction, gender by year interaction, and time to complete the exam affected final course grade. The significant gender effect was manifested in the final grade percentage of 75.9 \pm 0.4 for female students compared with $72.3 \pm 0.6$ for male students. Junior males had final course grades comparable with those of females, but sophomore and senior males had lower final course grades than other combinations. Biology majors had a final grade of 82.4 \pm 0.6 and this grade was greater than all other majors. Students classified as "other" had a final score of $74.4 \pm$ 0.8 , which was greater than agricultural science majors $(69.5 \pm 0.9)$. The APSC grade $(72.6 \pm 0.5)$ was higher than the agricultural science majors. Junior students had significantly greater final grades $(76.1 \pm 0.5)$ than sophomores $(73.3 \pm 0.6)$ and seniors $(72.9 \pm 0.9)$. All biology students had greater final grades than all other majors, but biochemistry juniors had greater final course grades than APSC, agricultural science, and dairy science juniors. "Other" seniors had greater final course grades than agricultural science seniors. The regression for time to complete the exam was curvilinear and suggests that highest exam scores were at about 90-min
\end{abstract}

Received December 12, 2013.

Accepted June 26, 2014.

${ }^{1}$ Corresponding author: guaz@vt.edu completion time. It may be that some male students need better preparation for anatomy and physiology and their educational preparation should mimic that of female students more in terms of advance-placement biology in high school. These results suggest that biology majors might be better prepared for animal anatomy and physiology than other students.

Key words: student success, physiology, anatomy, undergraduate

\section{Short Communication}

In upper-level undergraduate classes, instructors build upon concepts that students learned in previous coursework and should expect proficiency in academic skills/habits, and gender may play a role in this preparation. Gender inequities are found in high school where, currently, both boys and girls take equally demanding mathematics classes, but females are more likely to take advanced-placement courses in biology and chemistry than males. Girls also take more college preparatory and advanced-placement tests than boys (Buchmann et al., 2008). Gender inequity in college education has been of concern for incoming students for several years. Carbonaro et al. (2011) found that females have an $8.4 \%$ increase in college applications, but the admission rate for males and females is almost the same for 4-yr colleges; more females attend 2-yr colleges. In addition, about $4.5 \%$ more females receive a bachelor's degree compared with males and this may be traced back to their advantage in academic skills/habits obtained during high school. The student population majoring in animal sciences at Kansas State University (Manhattan) is approximately $70 \%$ female (Douthit et al. 2013) and this seems to be a trend nationally in animal science programs.

Factors studied to assess determinants of success in a genetics class included academic standing, major, and instructor (Bormann et al., 2013), but other factors also likely play a role (Gwazdauskas and McGilliard, 2014). Assessment completion times have been speculated to indicate proficiency with material. Anecdotal evidence suggests that students who complete exams quickly may not know the material well, whereas students who take 
the most time for an exam do very well. In contrast, Deiter and Pierce (1991) found that no significant relationship existed between students' finishing rank and their score in examinations in agricultural economics classes. Athanasou (1994) supported the idea that the time for test taking was an indicator of information processing. Exam-completion time needs further evaluation to determine if it is related to academic performance. The objective of this analysis was to determine factors that affect success in an undergraduate anatomy and physiology class.

Data were collected from 602 students enrolled in the Agriculture and Life Sciences (ALS) 2304 Animal Physiology and Anatomy course from 2005 through 2012, a core course for students in animal and poultry sciences (APSC) and dairy science (DASC) at Virginia Tech (Blacksburg). The course includes lecture- and laboratory-based portions. Majors of students at the time of completing the course were APSC $(\mathrm{n}=346)$; agricultural economics $(\mathrm{n}=12)$; agricultural sciences $(\mathrm{n}=33)$; agricultural technology $(\mathrm{n}=1)$; art $(\mathrm{n}=1)$; biochemistry $(\mathrm{n}=18)$; biological sciences $(\mathrm{n}=70)$; crop, soil, and environmental science $(\mathrm{n}=2)$; chemistry $(\mathrm{n}=1)$; communications $(\mathrm{n}=1)$; Commonwealth Campus (non-degree student status; $\mathrm{n}=1$ ); DASC (n $=87)$; English $(\mathrm{n}=1)$; environmental policy $(\mathrm{n}=1)$; food science and technology $(\mathrm{n}=1)$; fisheries and wildlife $(\mathrm{n}=2)$; forestry $(\mathrm{n}=1)$; human nutrition, foods, and exercise $(\mathrm{n}=1)$; history $(\mathrm{n}=1)$; interdisciplinary studies $(\mathrm{n}=4)$; mathematics $(\mathrm{n}=1)$; management $(\mathrm{n}=3)$; psychology $(\mathrm{n}=9)$; $\operatorname{sociology}(\mathrm{n}=1)$; and university studies $(\mathrm{n}=3)$. For statistical analyses the students' majors were APSC, agricultural sciences, biochemistry, biological sciences, DASC, and "other," which combined all other majors. There were 476 females (79\%) and 126 males (21\%). The year of study was sophomore, junior, or senior. The course lecture topics were homeostasis, cell structure and function, fundamental biochemical pathways, tissue structure and organization, the digestive system, the integumentary system, muscle physiology, the blood and heart, lymphatics, immunity, the nervous system, senses, the endocrine system, respiration, and the urinary system. Laboratories included gross anatomy; cell transport mechanisms and permeability; anatomy of the digestive system; the skeletal system; skeletal muscle anatomy; skeletal muscle contraction; cardiovascular anatomy and electrocardiogram; blood analysis; anatomy of the brain, spinal cord, and eye; reflexes and general senses; endocrine glands; renal anatomy and urinalysis; and bovine jugular cannulation and blood collection.

Final course grades were a composite of 4 lecture examinations (600 points), credit for written questions submitted at the end of lecture periods (50 points), 2 laboratory practicals (300 points), and weekly laboratory quizzes (100 points). The 3 lecture examinations administered during the semester had a time limit of $75 \mathrm{~min}$ and the noncomprehensive final examination at the end of the semester had a time limit of 120 min. Each lecture exam consisted of approximately $55 \%$ multiple-choice, $23 \%$ short-answer, and $22 \%$ true/ false questions. The amount of time used by students to complete the exams was recorded.

All analyses were performed with PROC GLIMMIX of SAS (SAS Institute Inc., Cary, NC). The dependent variable was final course grade in the class. The independent variables were gender, major, year of matriculation, significant interactions of major by year and gender by year, time for taking the examination, and time squared. In initial analyses, other interactions proved to be nonsignificant, as did the calendar year effect. Freshmen $(\mathrm{n}=15)$, graduate students $(\mathrm{n}=$ 4 ), and students majoring in the agriculture technology program $(\mathrm{n}=1)$ were removed from the data set. Students majoring in agricultural economics; art; crop, soil, and environmental science; chemistry; communications; Commonwealth Campus; English; environmental policy; food science and technology; fisheries and wildlife; forestry; human nutrition, foods, and exercise; history; interdisciplinary studies; mathematics; management; psychology; sociology; and university studies were coded as "other" in the data set.

The significant gender effect $(P<0.0001)$ was manifest in the final course grade of $75.9 \pm 0.4 \%$ for female students compared with $72.3 \pm 0.6 \%$ for male students. Vallejos et al. (2012) considered the importance of motivation, the desire for success, satisfaction, social prestige, and the possibility of academic achievement in students. Attitude and motivation may explain gender differences for college-aged females, as it was shown that females are more likely than males to expect before high school to attain at least a bachelor's degree, plan to attend college right after high school, and expect to enter an occupation that requires a college degree by age 30 (Carbonaro et al., 2011). Also, Buchmann et al. (2008) indicated better high school preparation for college for females than for males in the rigor of coursework. In contrast, no gender difference existed in final course grades in an undergraduate genetics class (Bormann et al., 2013). But at the same institution, a tendency existed for females to have greater academic performance in an equine science class (Douthit et al., 2013).

The effect of major is shown in Table 1. Biology students' final score of $82.4 \pm 0.6 \%$ was higher than that of all listed majors. Students classified as "other" had a final score of $74.4 \pm 0.8 \%$, which was higher than that of agricultural science majors $(69.5 \pm 0.9 \%)$. The 
APSC score $(72.6 \pm 0.5 \% ; P=0.030)$ was also higher than that of the agricultural science majors. Although Bormann et al. (2013) found no difference in final score in genetics between animal science majors and non-majors, they did find that preveterinary students scored higher than other students and suggested that students attempting to gain admission to veterinary school were more motivated by grades and that the veterinary school at Kansas State University required genetics. It may be that the biology students in anatomy and physiology were more motivated than other students because they aspired to medical or veterinary school. In an upper-level horse science class, Douthit et al. (2013) found that animal science majors performed better in the class than non-majors, but no differences existed in preveterinary compared with non-preveterinary students, suggesting that students perform well in their majors.

Table 2 shows the final score means by year of matriculation. Junior students had significantly higher final course grades $(76.1 \pm 0.5 \%)$ than sophomores $(73.3 \pm 0.6 \%)$ and seniors $(72.9 \pm 0.9 \%)$. These results conflict with Bormann et al. (2013), who found that upperclassmen did better than freshman in genetics. It may be that junior students were more prepared for the rigors of anatomy and physiology than sophomores and seniors. Also, it may be that seniors delayed completion of this course and only needed to pass it to graduate at the end of the semester, as this was a spring semester class. In contrast, class standing did not have a significant effect on student performance in an upper-level horse science class (Douthit et al., 2013).

Table 3 shows the significant interaction of major by year of matriculation. In general, junior biology and biochemistry students had higher final course grades than APSC, agricultural science, and DASC students. Sophomore and senior biology students perform bet-

Table 1. Least squares means and SE for final score (\%) in undergraduate anatomy and physiology by student's major field of study

\begin{tabular}{lll}
\hline Major & Mean & SE \\
\hline Animal and poultry sciences & $72.6^{\mathrm{bc}}$ & 0.5 \\
Agricultural science & $69.5^{\mathrm{c}}$ & 0.9 \\
Biochemistry & $73.0^{\mathrm{bc}}$ & 1.6 \\
Biology & $82.4^{\mathrm{a}}$ & 0.6 \\
Dairy science & $72.8^{\mathrm{bc}}$ & 0.8 \\
Other $^{1}$ & $74.4^{\mathrm{b}}$ & 0.8 \\
\hline
\end{tabular}

\footnotetext{
${ }^{a-c}$ Means with different superscript letters differ at $P<0.0001$.

${ }^{1}$ The major "other" included agricultural economics; art; crop, soil, and environmental science; chemistry; communications; Commonwealth Campus (non-degree student status); English; environmental policy; food science and technology; fisheries and wildlife; forestry; human nutrition, foods, and exercise; history; interdisciplinary studies; mathematics; management; psychology; sociology; and university studies.
}

Table 2. Least squares means and $\mathrm{SE}$ of final score (\%) in an undergraduate anatomy and physiology class by year of matriculation

\begin{tabular}{lcc}
\hline $\begin{array}{l}\text { Matriculation } \\
\text { year }\end{array}$ & Mean & SE \\
\hline Sophomore & $73.3^{\mathrm{b}}$ & 0.6 \\
Junior & $76.1^{\mathrm{a}}$ & 0.5 \\
Senior & $72.9^{\mathrm{b}}$ & 0.9 \\
\hline
\end{tabular}

${ }^{\mathrm{a}, \mathrm{b}}$ Means with different superscript letters differ at $P<0.0001$.

ter than all other sophomore and senior majors. Senior students classified as "other" had higher final course grades than senior agricultural science majors. These results suggest that biology students who take an animal anatomy and physiology class may be more prepared to excel, based on their coursework preparation, expanding on the finding of differences between majors of Douthit et al. (2013).

Table 4 shows the interaction of gender by year for final score in undergraduate anatomy and physiology. It appears that female students, regardless of year of matriculation, had similar final course grades. Junior males had final course grades comparable with those of females, but the sophomore and senior males had lower final course grades than the other combinations. This finding may be related to gender differences in academic skills and habits, as Carbonaro et al. (2011) found that females had an advantage over males in college completion. The final course grades are in contrast

Table 3. Least squares means and SE of final score (\%) by the major by year of matriculation interaction

\begin{tabular}{llcc}
\hline \multirow{2}{*}{ Major } & $\begin{array}{l}\text { Matriculation } \\
\text { year }\end{array}$ & Mean & SE \\
\hline Animal and poultry sciences & Sophomore & $74.1^{\mathrm{d}}$ & 0.4 \\
& Junior & $71.7^{\mathrm{a}}$ & 0.5 \\
& Senior & $72.0^{\mathrm{a}}$ & 1.6 \\
Agricultural science & Sophomore & $71.6^{\mathrm{a}}$ & 1.4 \\
& Junior & $70.1^{\mathrm{a}}$ & 1.2 \\
Biochemistry & Senior & $66.9^{\mathrm{a}}$ & 1.9 \\
& Sophomore & $69.6^{\mathrm{a}}$ & 2.7 \\
\multirow{4}{*}{ Biology } & Junior & $80.3^{\mathrm{b}}$ & 1.3 \\
& Senior & $69.1^{\mathrm{a}}$ & 3.6 \\
\multirow{3}{*}{ Dairy science } & Sophomore & $79.5^{\mathrm{b}}$ & 1.1 \\
& Junior & $85.5^{\mathrm{c}}$ & 0.9 \\
\multirow{2}{*}{ Other $^{1}$} & Senior & $82.2^{\mathrm{b}}$ & 1.0 \\
& Sophomore & $73.1^{\mathrm{d}}$ & 0.6 \\
& Junior & $74.4^{\mathrm{d}}$ & 1.2 \\
& Senior & $71.0^{\mathrm{a}}$ & 2.1 \\
& Sophomore & $72.0^{\mathrm{a}}$ & 1.1 \\
& Junior & $75.0^{\mathrm{d}}$ & 1.4 \\
& Senior & $76.2^{\mathrm{d}}$ & 1.5 \\
\hline
\end{tabular}

\footnotetext{
${ }^{\mathrm{a}-\mathrm{d}}$ Means with different superscript letters differ at $P<0.02$.

${ }^{1}$ The major "other" included agricultural economics; art; crop, soil, and environmental science; chemistry; communications; Commonwealth Campus; English; environmental policy; food science and technology; fisheries and wildlife; forestry; human nutrition, foods, and exercise history; interdisciplinary studies; mathematics; management; psychology; sociology; and university studies.
} 
Table 4. Least squares means and SE for final score (\%) by the gender by year of matriculation interaction

\begin{tabular}{llcc}
\hline \multirow{2}{*}{ Gender } & Matriculation & & \\
\hline Female & year & Mean & SE \\
& Sophomore & $76.0^{\mathrm{a}}$ & 0.6 \\
\multirow{3}{*}{ Male } & Junior & $76.2^{\mathrm{a}}$ & 0.5 \\
& Senior & $75.6^{\mathrm{a}}$ & 1.0 \\
& Sophomore & $70.6^{\mathrm{b}}$ & 0.8 \\
& Junior & $76.1^{\mathrm{a}}$ & 0.7 \\
& Senior & $70.2^{\mathrm{b}}$ & 1.3 \\
\hline
\end{tabular}

${ }^{\mathrm{a}, \mathrm{b}}$ Means with different superscript letters differ at $P<0.0001$.

to the findings of Bormann et al. (2013), who did not find a gender by year of study interaction. They found that seniors scored highest in their genetics class, but no difference existed in final course grades for sophomores and juniors.

The linear and quadratic terms for time taking the exam were significant $(P<0.0001$; Figure 1$)$ and suggest that about $75 \%$ of the time allotted for the exam resulted in higher final course grades. Similar results were obtained when only the three 75 -min exams were evaluated for relationships to final course grade. Becker and Suls (1982) found the hard-driving and competitive component of a type A behavior pattern had a positive

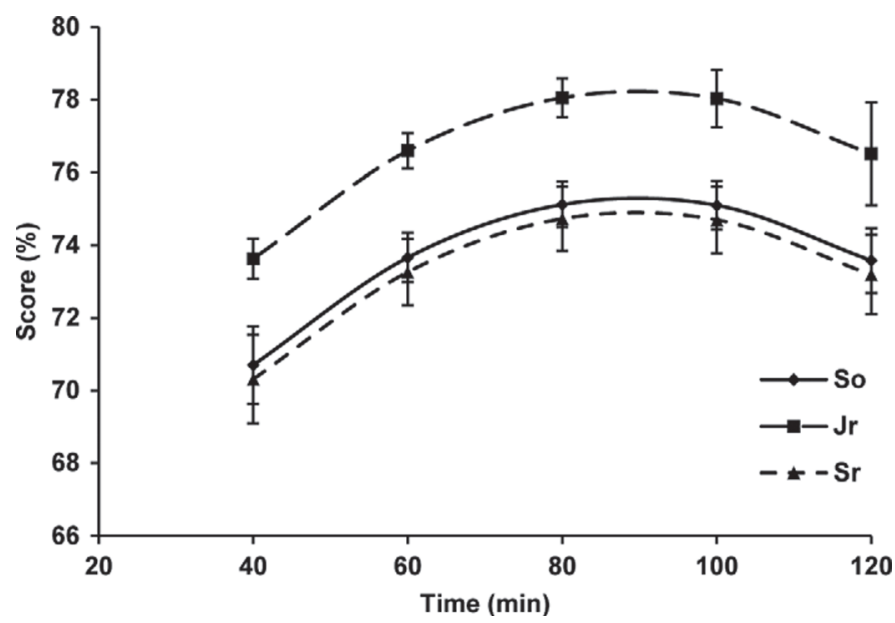

Figure 1. Relationship of time to complete examinations and final score by year of matriculation. Sophomore (So), junior (Jr), and senior $(\mathrm{Sr})$ regressions are depicted. relationship with time on test and test scores. Reporting on an agricultural marketing class with 85 undergraduates, Deiter and Pierce (1991) found a trend for a positive correlation between completion time and score rankings for students on the second hourly exam, suggesting that students who performed the best tended to finish earlier and students who finished early on the first exam also tended to finish early on the second exam. However, Athanasou (1994) found negative correlations between the length of time taken for tests and overall test scores, negating the assumption that speed of test completion be considered a gross measure of information processing.

In conclusion, these results suggest that preparation for undergraduate anatomy and physiology appears better for biology students than other majors, although career objectives of non-majors in an undergraduate anatomy and physiology class might be part of the influence. Female students do better and this might be related to preparation completed in high school. It may be that there should be greater investment in science, technology, engineering, and mathematics (STEM) programs in high school and college.

\section{REFERENCES}

Athanasou, J. A. 1994. Performance differences on an untimed test: Some Australian and New Zealand data from high school pupils and job applicants. Pers. Individ. Dif. 16:799-800.

Becker, M. A., and J. Suls. 1982. Test performance as a function of the hard-driving and speed components of the type A coronary-prone behavior pattern. J. Psychosom. Res. 26:435-440.

Bormann, J. M., D. W. Moser, and K. E. Bates. 2013. Factors affecting student performance in an undergraduate genetics course. J. Anim. Sci. 91:2438-2443.

Buchmann, C., T. A. DiPrete, and A. McDaniel. 2008. Gender inequalities in education. Annu. Rev. Sociol. 34:319-337.

Carbonaro, W. W., B. J. Ellison, and E. Covay. 2011. Gender inequalities in the college pipeline. Soc. Sci. Res. 40:120-135.

Deiter, R., and V. Pierce. 1991. Student test scores and their relationship to order of test completion. North Am. Coll. Teachers Agric. J. $35: 38-41$.

Douthit, T. L., J. M. Bormann, and J. M. Kouba. 2013. A retrospective look at students enrolled in an upper-level horse science class: Factors that affect classroom performance. J. Anim. Sci. 91:2976-2984.

Gwazdauskas, F. C., and M. L. McGilliard. 2014. Characteristics of success in a graduate physiology course. North Am. Coll. Teachers Agric. J. 59:19-23.

Vallejos, M., J. M. Alvarado, and A. Puente. 2012. College performance prediction test. Procedia Soc. Behav. Sci. 31:846-851. 